\title{
Late Oligocene Warming Event in the southern North Sea Basin: benthic foraminifera as paleotemperature proxies
}

\author{
E. De Man' ${ }^{1} \&$ S. Van Simaeys ${ }^{2}$
}

1 Royal Belgian Institute of Natural Sciences, Vautierstraat 29, B-1000 Brussels, Belgium. E-mail: Ellen.deman@naturalsciences.be (corresponding author)

2 Historical Geology, University of Leuven, Redingenstraat 16, B-3000 Leuven, Belgium

Manuscript received: February 2004; accepted: August 2004

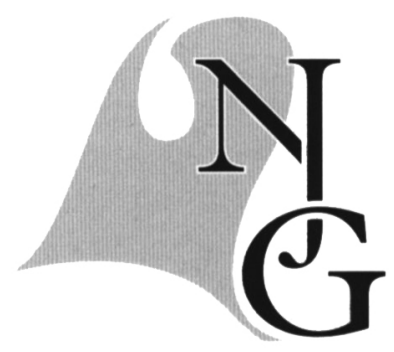

\begin{abstract}
The investigation of foraminiferal assemblages from a series of Oligocene borehole sections allowed paleoenvironment and paleoclimate reconstructions for the Rupelian and Chattian (Lower and Upper Oligocene) Stages in their type region, the southern North Sea Basin. A striking feature coinciding with the Rupelian-Chattian (R-C) unconformity is the major change in paleotemperature and paleobathymetry. The shallow marine to restricted marine subtropical fauna at the base of the Chattian is in strong contrast with the deeper marine and cooler upper Rupelian assemblages. This study suggests that the early Chattian transgression is genetically related to a widespread major warming pulse, known as the Late Oligocene Warming Event.
\end{abstract}

Keywords: benthic foraminifera, global warming, Oligocene, paleotemperature, Rupelian-Chattian boundary

\section{Introduction}

As most of the Paleogene climatic and oceanographic studies focused on intervals of presumed rapid global change and biotic extinctions, such as those at the Cretaceous-Tertiary (K-T), Paleocene-Eocene or Eocene-Oligocene boundary, most researches did not further explore the remainder of the Paleogene geological archive. This has led to the generally accepted assumption that, since the Early Eocene Climatic Optimum (or 'EECO', e.g., Zachos et al., 2001), a long-termed, gradual and pervasive global deterioration of the earth's climate resulted in a unidirectional cooling and the development of a significant Arctic and Antarctic cryosphere, as known from the present earth conditions (Ivany et al., 2003). However, detailed deep-sea benthic $\delta^{18} \mathrm{O}$ studies from continuous ODP holes show that the presumed gradual climatic trend is characterised by strong short-term fluctuations. A series of warmer (e.g., the 'Middle Eocene Climatic Optimum', Bohaty \& Zachos, 2003; the 'Late Oligocene Warming Event' and 'Mid Miocene Climatic Optimum', Zachos et al., 2001), and colder intervals (e.g., the Oi- and Mi-'events' or 'glaciations', Miller et al., 1987, 1991, 1998; Zachos et al., 1993, 1994, 1996, 1999, 2001) were recognised, and correlated around both hemispheres. While the impact and significance of these events now begins to be realised by the scientific community, clearly influencing our understanding of the nature of long- and short-term climate changes, only few speculations on possible underlying mechanisms have been put forward (Bohaty \& Zachos, 2003).

We here report on a drastic climate change associated with the base of the Chattian unit-stratotype in the southern North Sea Basin, recognised by means of benthic foraminiferal assemblages, and further suggest possible correlation with the Late Oligocene Warming Event of Zachos et al. (2001). 


\section{Geological setting}

Both the classic Lower- and Upper Oligocene unitstratotypes (respectively the Rupelian and Chattian Stages) were defined on the basis of southern North Sea Basin successions, and have been the topic of many (micro)paleontological, sedimentological and geochemical studies (for an overview see Van Simaeys et al., 2004). The R-C unconformity in the southern North Sea Basin is associated with major changes in benthic foraminiferal assemblages (De Man et al., 2004). The base of the Chattian sequence is characterised by the bloom of benthic foraminifer Asterigerinoides guerichi guerichi $(>70 \%)$. This distinct and widespread 'Asterigerina Horizon' can be recognised throughout the North Sea Basin (e.g., Ellermann, 1958; Indans, 1958, 1965; Doppert \& Neele, 1983; Ulleberg, 1987; King, 1983, 1989; De Man et al., 2004) and allows clear recognition of the $\mathrm{R}-\mathrm{C}$ boundary in its type region (Van Simaeys et al.,
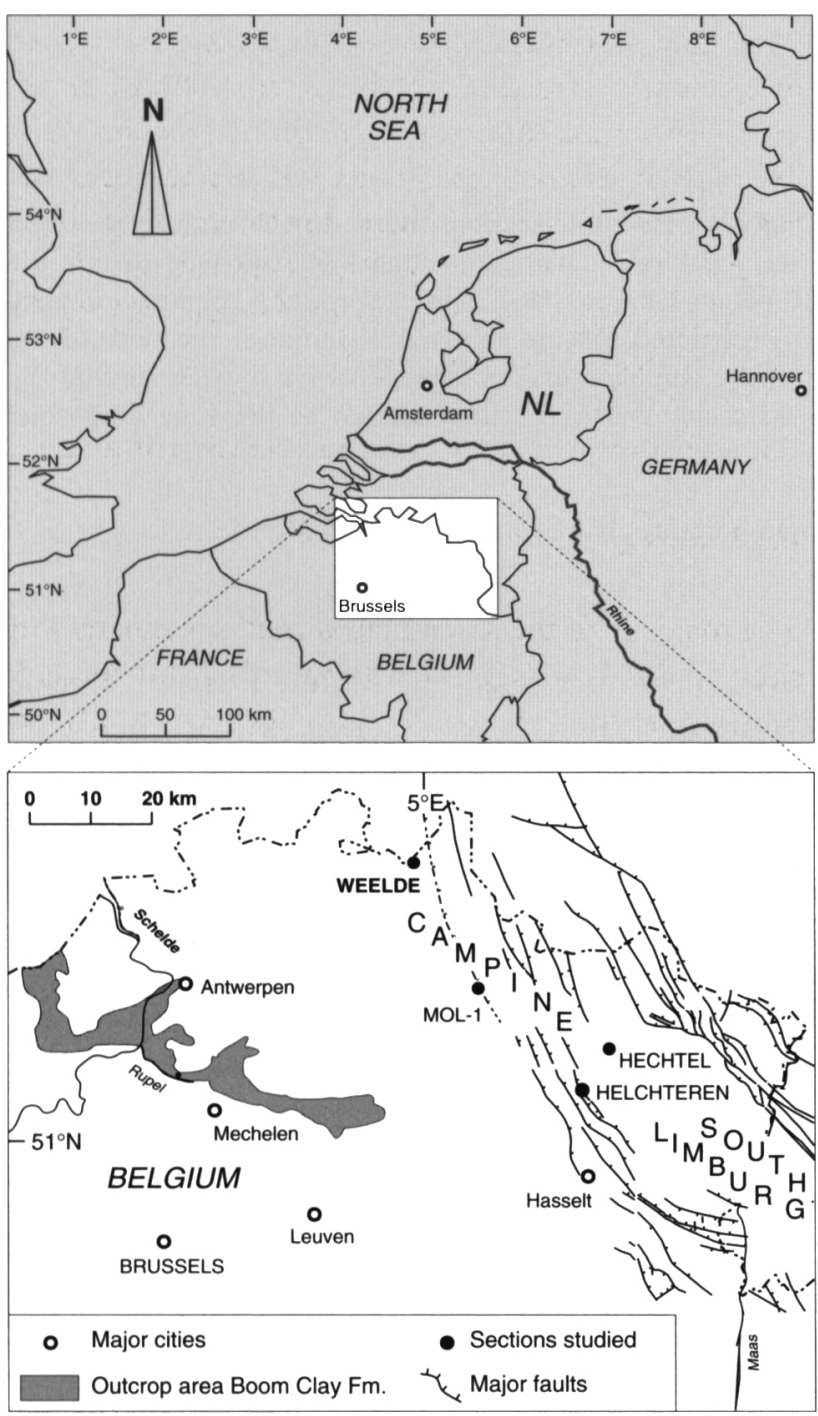

Fig. 1. Location of the sections studied (modified afterVan Simaeys et al., 2004).
2004). Other significant bio-events, coeval with the 'Asterigerina Horizon', are the first occurrences of Elphidium subnodosum and Protelphidium roemeri (De Man et al., 2004). Despite the fact that regional biostratigraphy achieves high resolution, chronostratigraphic calibration of these successions to the international time scale remains problematic, mainly due to the marginal to restricted marine nature of most deposits and the near absence of traditional, age-indicative calcareous microfossils. Recent dinoflagellate correlations, however, revealed that the R-C unconformity in the stratotype area is genetically related to the Oligocene Glacial Maximum (OGM, see Van Simaeys et al., submitted) and further suggest that the oldest of the time-transgressive glauconitic fine Chattian sands in the southern North Sea Basin were deposited around 26.7 Ma (Van Simaeys, 2004).

\section{Material \& Methods}

The benthic foraminiferal investigation is based on approximately 80 samples from 4 cored boreholes in NE Belgium, covering the Rupelian Boom Clay and the Chattian Voort Sand Formation (Fig. 1, see also De Man et al., 2004). These data are furthermore completed with published results from the lower part of the Boom Clay Formation (Hooyberghs et al., 1992; Grimm \& Steurbaut, 2001). A composite section (CS) for the R-C transition in the southern North Sea Basin is compiled on the basis of geophysical well $\log$ data and biostratigraphy. The 'Asterigerina Horizon' - defining the base of the Chattian Stage - is designated as reference level zero (see De Man et al., 2004).

Equally sized samples $(\sim 200 \mathrm{~g})$ were dried in an oven and then soaked in a dilute solution of a phosphatecontaining detergent ('Sun'). All samples were washed on a $63 \mu \mathrm{m}$ sieve, dried, and then split on a $120 \mu \mathrm{m}$ sieve. Only the fraction $>120 \mu \mathrm{m}$ was examined quantitatively. Relative abundances were calculated from at least 200 benthic individuals, except when the faunas were very sparse (Table 1 ; for details and range charts see De Man et al., 2004). For the lower part of the section (up to level S50), counts are limited to 100 benthic foraminifera per sample (data by Hooyberghs et al., 1992 and Grimm \& Steurbaut, 2001) and hence are statistically not representative. To recognise and evaluate post-mortem changes, i.e. dissolution and transport, the quality of preservation for the foraminiferal assemblages was evaluated (see e.g., Murray, 1984, p. 467). Only assemblages revealing minor postmortem modifications are applied in the present paleoenvironmental reconstructions. 




Fig. 2. Temperature ranges of selected, encountered taxa, as recorded in literature.

The planktonic foraminifera were not identified to species level, but only calculated as percentages $(\mathrm{P} \%=$ number planktonic / (number benthic + planktonic foraminifera) $] \times 100$ ). In a semi-enclosed basin, this value is not primarily related to depth but rather to the influx of oceanic water into the basin (Murray, 1976). The Fisher diversity index $(\alpha)$, allowing comparison with modern equivalent environments, is determined following standard procedures as described by Murray (1973). The three suborders (hyaline, porcellaneous and agglutinated forms) are taken into account for the triangular plot (Murray, 1973 , p. 26), and additional differentiation is made for calcareous and non-calcareous agglutinants (according to King, 1989), allowing recognition of low oxygen levels.

Temperature delineation for each genus is based on the assumption that the environmental conditions for modern genera are essentially the same as for the fossil record. This assumption is fairly reliable for
Cenozoic times (Murray, 1984, p. 469). Additionally, this assumption is evaluated through comparison with Oligocene shallow marine faunas from different paleogeographic provinces (e.g., Beckmann, 1953; Corliss, 1981; Wong, 1976; Wood et al., 1985). These approaches led to the establishment of 4 different categories, each category grouping species with a clear affinity towards respectively 'cold', 'temperate', 'warm' or 'cold to warm' conditions (Table 1). Quantification of these temperature-restricted ecogroups is based on comprehensive lists of temperature preferences for modern benthic foraminifera (e.g., Jarke, 1961; Haake, 1962; Hofker, 1977; Murray, 1973, 1991; see Table 1 and Fig. 2).

These data allow the reconstruction of a paleotemperature curve according to the equation of Lommerzheim (1991); a method successfully applied for late Oligocene samples (Kohnen, 1995):

$$
\mathrm{T}_{\text {trend }}=(1 / \mathrm{n}) \sum_{\mathrm{i}=1}^{\mathrm{n}} \mathrm{n}_{\mathrm{i}} *\left[\left(\mathrm{~T}_{\min , \mathrm{i}}+\mathrm{T}_{\max , \mathrm{i}}\right) / 2\right]
$$

With i representing a certain taxon, $\mathrm{n}$ the total amount of specimens counted within the assemblage, $n_{i}$ the appropriate number of specimens of taxon $i$ and $T_{\min , i}$, $\mathrm{T}_{\text {max }, \mathrm{i}}$ its minimum and maximum temperature (see Fig. 2). It is here stressed that this method only provides a trend value for comparing the different assemblages, and should not be regarded as an absolute method for determining paleotemperatures.

\section{Paleoenvironment: results and interpretation}

\section{Evaluation of the assemblage-quality}

The majority of the assemblages yield specimens with shiny to dull hyaline tests, with juveniles and adults of the same species present, and broken tests being very rare. There is no significant loss of agglutinated tests, as indicated by the presence of both adult and juvenile Karreriella siphonella. Hence, these assemblages are regarded as reliable for paleoecological interpretations (field I of Murray, 1984, p. 467). Some upper Rupelian samples (around $-74 \mathrm{~m}$ and $-55 \mathrm{~m}$ in the $\mathrm{CS}$ ) are anomalously enriched in pyritised agglutinants (medium to large agglutinated tests), suggesting dissolution of hyaline calcareous tests. The latter assemblages are assigned to field IIICC (Murray, 1984, p. 467), and hence cannot be used in further paleoenvironmental reconstructions.

\section{Results}

The Fisher diversity index ( $\alpha$ index), representing the assemblage diversity, is high for the lower part of the 
Table 1. Quantitative distribution of environmental important benthic foraminiferal taxa from the Weelde (W), Hechtel (He) and Helchteren (Hr) borehole. Grey zones indicate statistically not representative samples.

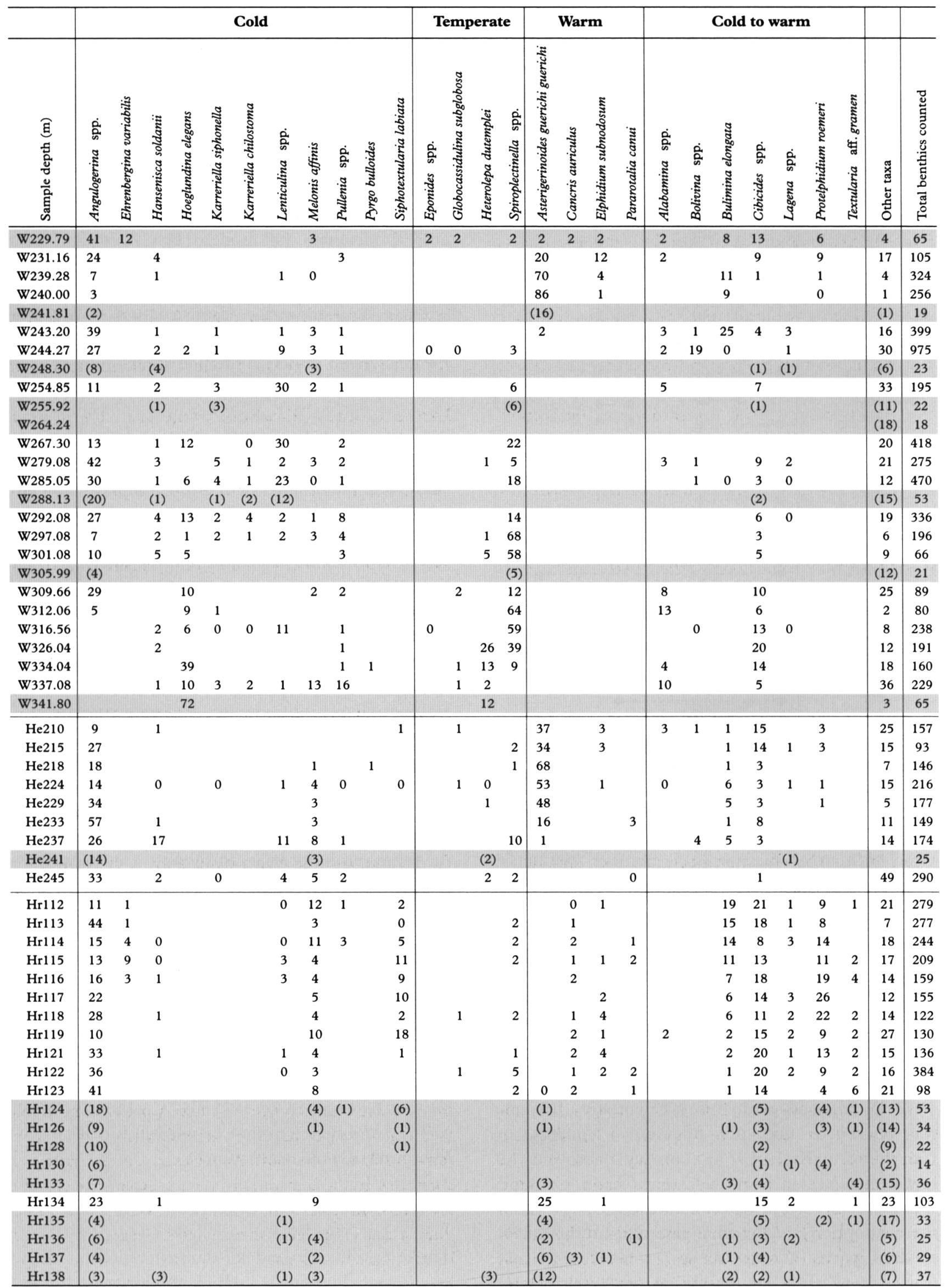


Rupelian section (for the interval -130 to $-90 \mathrm{~m}$ : $\alpha$ values vary between 7 and 16) and gradually declines for the upper Rupelian samples (for the interval -90 to $0 \mathrm{~m}: \alpha$ values vary between 3 and 7; see Table 2 and Fig. 3). One upper Rupelian sample, i.e. $-37 \mathrm{~m}$ in the CS, shows an unexpected high $\alpha$ index (see Table 2 and Fig. 3). The Fisher diversity index for the base of the Chattian succession is distinctly lower compared to the Rupelian assemblages (for the interval 0 to $10 \mathrm{~m}$ : $\alpha$ values vary between 1 and 4, Fig. 3). Higher up the Chattian, the Fisher diversity index increases again, reaching maximum values around 43 and $48 \mathrm{~m}$ in the CS (Fig. 3).

In general, planktonic foraminifera are rare throughout the Oligocene southern North Sea Basin successions. Only in the lower part of the Rupelian section, planktonic foraminifera are more common, and reach maximum values around $-118 \mathrm{~m}$ in the $\mathrm{CS}(\mathrm{P} \sim 50 \%$, Fig. 3, Table 2). In the upper part of the section, planktonic foraminifera are very rare $(<5 \%)$, except for 3 levels $(-95,-74$ and $43 \mathrm{~m})$, showing values around $\sim 17 \%$. The Oligocene southern North Sea Basin foraminiferal assemblages are furthermore dominated by hyaline taxa. The porcellaneous component shows slightly higher values in the Chattian as compared to the Rupelian assemblages, whereas noncalcareous agglutinants are more represented within the Rupelian (Fig. 3).

\section{Interpretation}

The foraminiferal assemblages from the lower part of the Rupelian successions suggest normal marine shelf conditions ( $100 \mathrm{~m}$ water depth), based on a high Fisher diversity index $(\alpha>7)$ and the proportion of hyaline taxa on the triangular plot (Murray, 1991) (see Fig. 3). The common occurrence of planktonic foraminifera further suggests open marine connections to the oceanic realm (Grimm \& Steurbaut, 2001); the maximum abundance of planktonic foraminifera in $-118 \mathrm{~m}$ coincides with a maximum flooding surface (Vandenberghe et al., 2001). The upper Rupelian foraminiferal assemblages $(-90 \mathrm{~m}$ to $0 \mathrm{~m}$ ), showing a lower diversity index and rare planktonic foraminifera, suggest a gradual shallowing of a poorly ventilated and more isolated marine environment (Van Simaeys et al., 2004). The increased assemblage diversity around $-37 \mathrm{~m}(\alpha$ index $=10)$, coinciding with the recurrence of several dinocyst taxa and the first occurrence of some calcareous nannoplankton species (Van Simaeys et al., 2004), suggests a renewed opening of a marine pathway and the inflow of well-oxygenated water masses, re-installing normal marine conditions. The basal Chattian foraminiferal assemblage suggests marginal marine to brackishmarine conditions, with water depths not exceeding $20 \mathrm{~m}$. The glauconiferous sandy substrate points towards increased hydrodynamic energy compared to the upper Rupelian successions. Higher up the Chattian, conditions return to a normal marine environment.

\section{Paleotemperature: results and interpretation}

\section{Evaluation of the encountered taxa}

Temperature delineation for the different ecogroups and - if specified - for different taxa is based on values listed in literature (see Fig. 2). In case different temperature-ranges were listed for the same taxon, the maximum range was taken into account and used in the equation of Lommerzheim (1991) (see above). Extinct taxa (e.g. Rotaliatina) and taxa with no clear or unknown affinity towards specific climatic conditions (e.g. nodosariids) are grouped as 'other taxa' (see Table 1) and are not used in the present paleoenvironmental analysis.

Asterigerinoides guerichi guerichi, originally described as Asterigerina guerichi Franke, 1912, is here considered to have the same paleoecological preferences as the genus Asterigerina. The latter genus is reported as an inner shelf species occurring in subtropical to tropical conditions (Murray, 1991, p. 288 \& p. 323). Asterigerinoides is reported from late Eocene sections in northern Italy, with presumed water temperatures exceeding $22^{\circ} \mathrm{C}$ (Murray, 1991, p. 308). In the late Oligocene North Sea Basin successions, Asterigerinoides guerichi guerichi co-occurs with Miogypsina (Anderson et al., 1971), a larger foraminifera, clearly favouring warm subtropical conditions. The affinity of Pararotalia towards warm conditions is confirmed by Lauriat-Rage et al. (1993); this taxon is believed to have a temperature preference between 15 and $25^{\circ} \mathrm{C}$. Also the keeled Elphidium subnodosum is regarded as a typical shelf species, favouring warm conditions (Murray, 1991, p. 129 \& p. 324).

Globocassidulina subglobosa is listed as a cold temperate to temperate species in modern faunas, occurring in water masses between 4 and $20^{\circ} \mathrm{C}$ (Murray, 1991 , p. 80 \& p. 159). In Oligocene times, however, this species tends to prefer much warmer conditions (see e.g. Wood et al., 1985 and Corliss, 1981). The same holds true for both Eponides spp. and Heterolepa dutemplei. In modern faunas these species have affinity towards cold temperate to temperate conditions, while during the Oligocene, these species frequently occur in subtropical regions. 
Table 2. Foraminiferal paleoenvironment parameters for the Oligocene southern North Sea Basin successions. Sample depth refers to the exact depth in the appropriate borehole or outcrop section (Hr: Helchteren borehole; He: Hechtel borehole; W: Weelde borehole; TW: Terhagen West; SN: Sint Niklaas). Counts not exceeding 100 specimens per sample are indicated in grey.

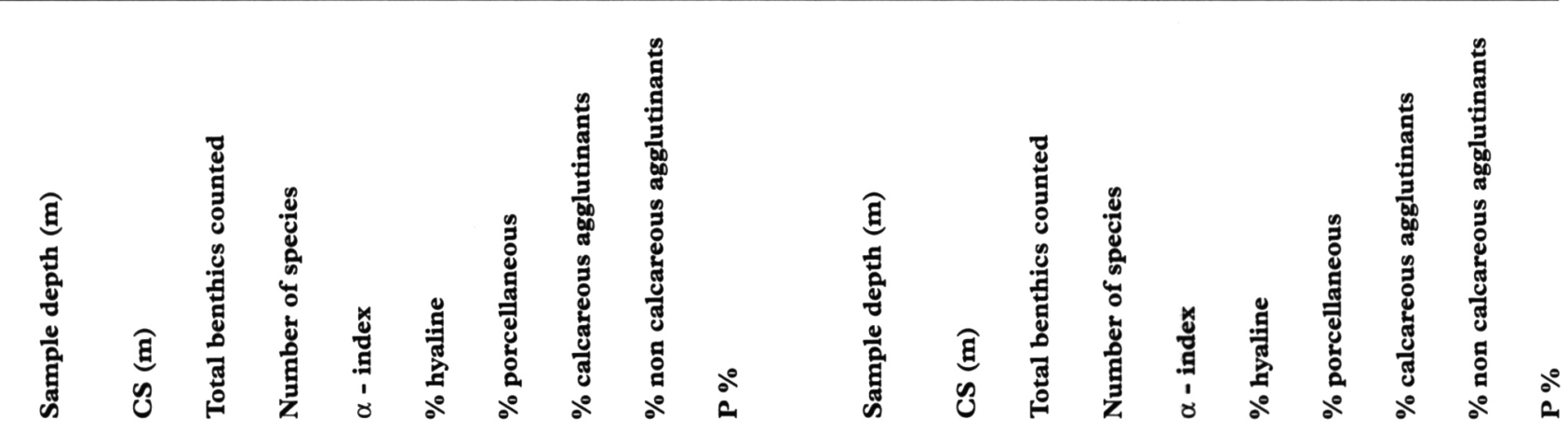

\begin{tabular}{|c|c|c|c|c|c|c|c|c|c|}
\hline Hr1 12 & 50 & 279 & 26 & 7 & 92 & 5 & 2 & 1 & 0 \\
\hline Hr1 13 & 49 & 277 & 20 & 5 & 97 & 1 & 2 & 0 & 0 \\
\hline Hr1 14 & 48 & 244 & 31 & 10 & 91 & 2 & 7 & 0 & 0 \\
\hline Hr1 15 & 47 & 209 & 29 & 9 & 82 & 3 & 13 & 2 & 1 \\
\hline Hr116 & 47 & 159 & 20 & 6 & 84 & 3 & 9 & 4 & 3 \\
\hline W 229 & 46 & 65 & 19 & 7 & 98 & 0 & 2 & 0 & 12 \\
\hline Hr117 & 45 & 155 & 17 & 5 & 86 & 3 & 10 & 0 & 0 \\
\hline Hr 118 & 44 & 122 & 22 & 8 & 92 & 3 & 3 & 2 & 2 \\
\hline Hr119 & 43 & 130 & 27 & 11 & 74 & 5 & 19 & 2 & 16 \\
\hline Hr121 & 41 & 136 & 23 & 9 & 90 & 4 & 3 & 2 & 4 \\
\hline Hr122 & 40 & 384 & 32 & 9 & 89 & 5 & 4 & 2 & 2 \\
\hline Hr123 & 39 & 98 & 20 & 7 & 87 & 5 & 2 & 6 & 6 \\
\hline Hr124 & 38 & 53 & & & & & & & \\
\hline Hr126 & 36 & 34 & & & & & & & \\
\hline W 231 & 30 & 105 & 18 & 6 & 100 & 0 & 0 & 0 & 4 \\
\hline Hr134 & 28 & 103 & & & & & & & 1 \\
\hline $\mathrm{He} 210$ & 26 & 157 & 23 & 7 & 95 & 4 & 1 & 0 & 6 \\
\hline Hr138 & 25 & 37 & & & & & & & \\
\hline $\mathrm{He} 215$ & 20 & 93 & 14 & 4 & 97 & 1 & 2 & 0 & 1 \\
\hline He 218 & 18 & 146 & 13 & 3 & 98 & 1 & 1 & 0 & 0 \\
\hline $\mathrm{He} 224$ & 12 & 216 & 26 & 7 & 97 & 2 & 1 & 0 & 1 \\
\hline He229 & 7 & 177 & 11 & 3 & 100 & 0 & 0 & 0 & 1 \\
\hline W 239 & 3 & 324 & 15 & 3 & 100 & 0 & 0 & 0 & 0 \\
\hline $\mathrm{He} 233$ & 3 & 149 & 15 & 4 & 99 & 1 & 0 & 0 & 4 \\
\hline W 240 & 2 & 256 & 6 & 1 & 100 & 0 & 0 & 0 & 0 \\
\hline W 241 & 1 & 19 & & & & & & & \\
\hline W 242 & 0 & 0 & & & & & & & \\
\hline W 243 & -1 & 399 & 26 & 6 & 97 & 1 & 1 & 1 & 1 \\
\hline $\mathrm{He} 237$ & -1 & 174 & 20 & 6 & 90 & 0 & 10 & 0 & 1 \\
\hline W 244 & -2 & 975 & 36 & 7 & 95 & 0 & 4 & 1 & 2 \\
\hline He241 & -5 & 25 & & & 100 & & & & 4 \\
\hline W 248 & -6 & 23 & & & 100 & & & & \\
\hline He 245 & -9 & 290 & 19 & 5 & 98 & 0 & 2 & 0 & 1 \\
\hline W 252 & -10 & 0 & & & 100 & & & & 0 \\
\hline W 254 & -12 & 195 & 24 & 7 & 92 & 0 & 5 & 3 & 3 \\
\hline W 260 & -18 & 0 & & & 100 & & & & \\
\hline W 267 & -25 & 418 & 14 & 3 & 77 & 0 & 22 & 0 & 0 \\
\hline W 272 & -30 & 0 & & & 100 & & & & \\
\hline W 276 & -34 & 0 & & & 100 & & & & \\
\hline W 279 & -37 & 275 & 34 & 10 & 87 & 1 & 6 & 6 & 1 \\
\hline W 285 & -43 & 470 & 23 & 5 & 77 & 0 & 17 & 6 & 0 \\
\hline W 288 & -46 & 53 & & & 100 & & & & \\
\hline W 292 & -50 & 336 & 22 & 5 & 79 & 1 & 14 & 6 & 1 \\
\hline W 297 & -55 & 196 & 20 & 5 & 27 & 1 & 69 & 3 & 2 \\
\hline
\end{tabular}

\begin{tabular}{|c|c|c|c|c|c|c|c|c|c|}
\hline W 301 & -59 & 66 & & & 100 & & & & \\
\hline W 305 & -64 & 21 & & & 100 & & & & \\
\hline W 309 & -67 & 89 & 11 & 3 & 88 & 0 & 12 & 0 & 0 \\
\hline W 312 & -70 & 80 & 8 & 3 & 34 & 1 & 65 & 0 & 0 \\
\hline W 316 & -74 & 238 & 26 & 8 & 39 & 1 & 59 & 1 & 19 \\
\hline W 322 & -80 & 3 & & & 100 & & & & \\
\hline W 326 & -84 & 191 & 13 & 3 & 61 & 0 & 39 & 0 & 0 \\
\hline W 334 & -92 & 160 & 12 & 3 & 83 & 8 & 9 & 0 & 4 \\
\hline W 337 & -95 & 229 & 22 & 6 & 92 & 2 & 0 & 6 & 21 \\
\hline TW 51 & -103.5 & 100 & 24 & 11 & 100 & 0 & 0 & 0 & 21 \\
\hline W 341 & -105 & 65 & & & 100 & & & & \\
\hline TW 46 & -108 & 100 & 14 & 4,5 & 100 & 0 & 0 & 0 & 1 \\
\hline TW 43 & -110.5 & 100 & 21 & 8 & 98 & 0 & 1 & 1 & 13 \\
\hline TW 41 & -112.5 & 100 & 16 & 5 & 99 & 0 & 0 & 1 & 9 \\
\hline TW 18 & -118 & 100 & 25 & 11 & 92 & 0 & 8 & 0 & 87 \\
\hline TW 16 & -118.2 & 100 & 26 & 11 & 86 & 1 & 12 & 1 & 43 \\
\hline TW 15 & -118.4 & 100 & 23 & 10 & 95 & 0 & 5 & 0 & 26 \\
\hline TW 14 & -118.7 & 100 & 26 & 11 & 93 & 0 & 7 & 0 & 7 \\
\hline TW 13 & -119 & 100 & 22 & 8 & 95 & 0 & 5 & 0 & 60 \\
\hline TW 12 & -120 & 100 & 28 & 13 & 66 & 0 & 31 & 3 & 23 \\
\hline TW 11 & -120.5 & 100 & 20 & 7 & 93 & 0 & 6 & 1 & 34 \\
\hline TW 10 & -121 & 100 & 24 & 10 & 90 & 0 & 7 & 3 & 44 \\
\hline TW 9 & -121.5 & 100 & 28 & 13 & 88 & 1 & 11 & 0 & 21 \\
\hline TW 8 & -122 & 100 & 29 & 14 & 93 & 0 & 5 & 2 & 29 \\
\hline TW $8 b$ & -123 & 100 & 21 & 8 & 95 & 0 & 5 & 0 & 34 \\
\hline TW 7 & -124 & 100 & 25 & 11 & 97 & 1 & 1 & 1 & 34 \\
\hline TW 6 & -124.5 & 100 & 29 & 13 & 96 & 0 & 4 & 0 & 3 \\
\hline TW 5 & -125.5 & 100 & 28 & 12 & 92 & 0 & 8 & 0 & 5 \\
\hline TW 4 & -126 & 100 & 26 & 11 & 93 & 0 & 6 & 1 & 3 \\
\hline TW 3 & -126.4 & 100 & 26 & 11 & 92 & 0 & 6 & 2 & 3 \\
\hline TW 2 & -126.7 & 100 & 26 & 11 & 93 & 0 & 6 & 1 & 2 \\
\hline TW 1 & -127 & 100 & 22 & 8 & 84 & 0 & 15 & 1 & 11 \\
\hline TW 35 & -127.3 & 100 & 20 & 7 & 97 & 0 & 3 & 0 & 46 \\
\hline TW 34 & -127.5 & 100 & 24 & 10 & 94 & 0 & 1 & 5 & 24 \\
\hline SN 11 & -128 & 100 & 22 & 9 & 88 & 0 & 10 & 2 & 63 \\
\hline TW 33 & -128.5 & 100 & 26 & 12 & 90 & 0 & 8 & 2 & 2 \\
\hline SN 10 & -129 & 100 & 27 & 12 & 80 & 0 & 17 & 3 & 1 \\
\hline SN 9 & -129.5 & 100 & 29 & 13 & 97 & 0 & 3 & 0 & 12 \\
\hline TW 31 & -130 & 100 & 17 & 6 & 96 & 0 & 4 & 0 & 0 \\
\hline SN 8 & -131 & 100 & 23 & 7 & 95 & 0 & 4 & 1 & 7 \\
\hline SN 7 & -132 & 100 & 20 & 7 & 93 & 0 & 6 & 1 & 6 \\
\hline SN 5 & -134 & 100 & 32 & 16 & 86 & 0 & 10 & 4 & 26 \\
\hline SN 3 & -138 & 100 & 26 & 13 & 86 & 0 & 10 & 4 & 17 \\
\hline
\end{tabular}


Angulogerina spp., often used in synonymy with Trifarina spp., nowadays occurs in water masses with temperatures between 4 and $11^{\circ} \mathrm{C}$ (Murray, 1991, p. 251). From the Southern Ocean, this genus is even recorded in shelf deposits with water temperatures between -2 and $1^{\circ} \mathrm{C}$ (Murray, 1991, p. 274). Other

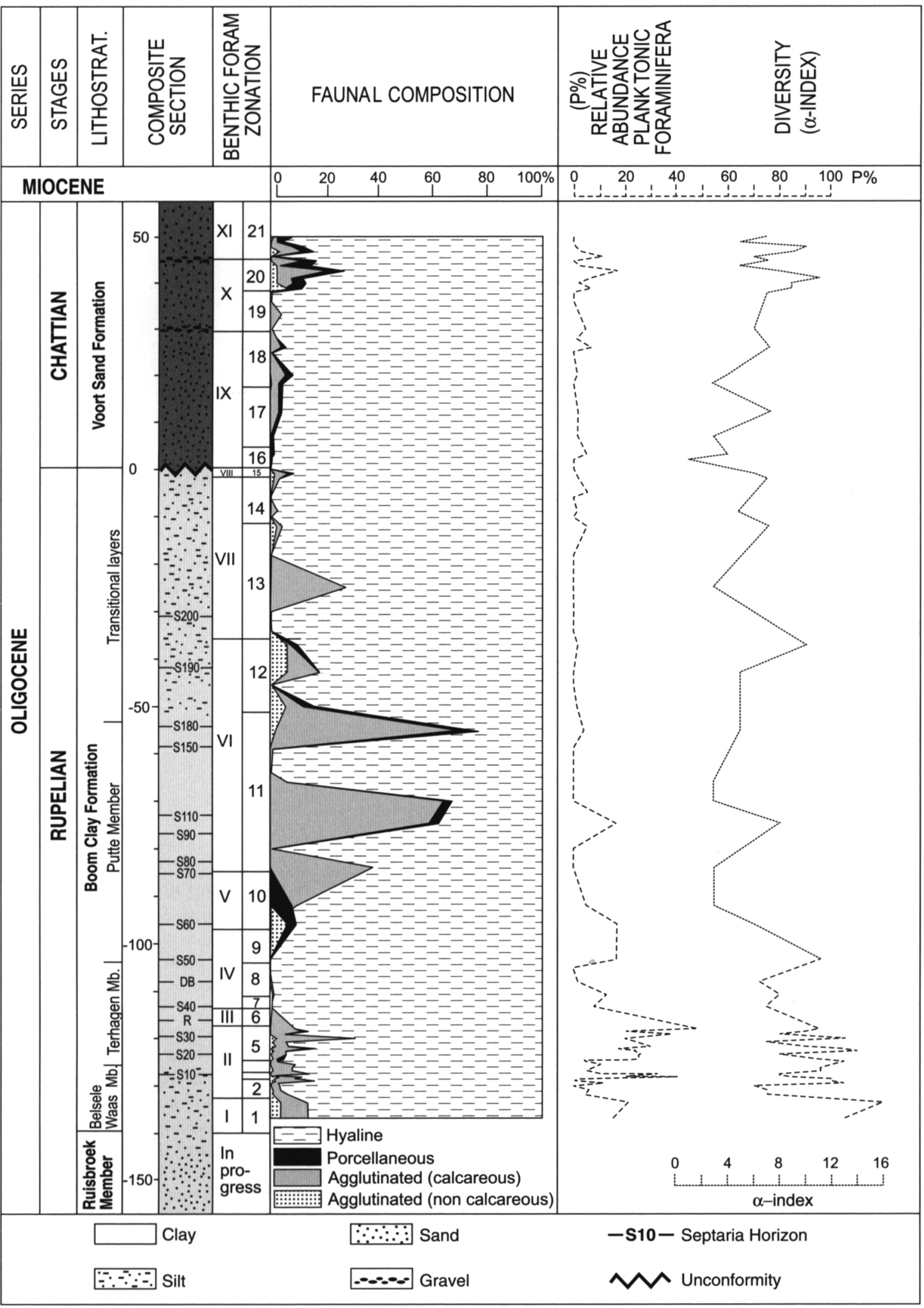

Fig. 3. Foraminiferal paleoenvironment parameters for the Oligocene southern North Sea Basin successions. Composite section and benthic foram zonations after De Man et al., 2004. Data from the outcrop section (up to S50) by Hooyberghs et al. (1992). Counts not exceeding 100 specimens per sample are indicated by dashed lines. 
recent cold water taxa (e.g. Karreriella, Lenticulina, Pullenia and Pyrgo) generally occur in water masses with temperatures not exceeding $10^{\circ} \mathrm{C}$.

The distribution of the genus Protelphidium, of which the modern representative is thought to be Haynesina (Murray, 1991, p. 136 \& p. 309), is primarily related to salinity. However, optimum temperature conditions for this genus are between 15 and $20^{\circ} \mathrm{C}$.
Results

A paleotemperature curve, based on the benthic foraminiferal assemblage for each sample and using the equation as explained above, has been constructed for the Oligocene southern North Sea Basin successions (Fig. 4). In general, the Rupelian assemblages are dominated by cold to cold-temperate taxa (i.e.

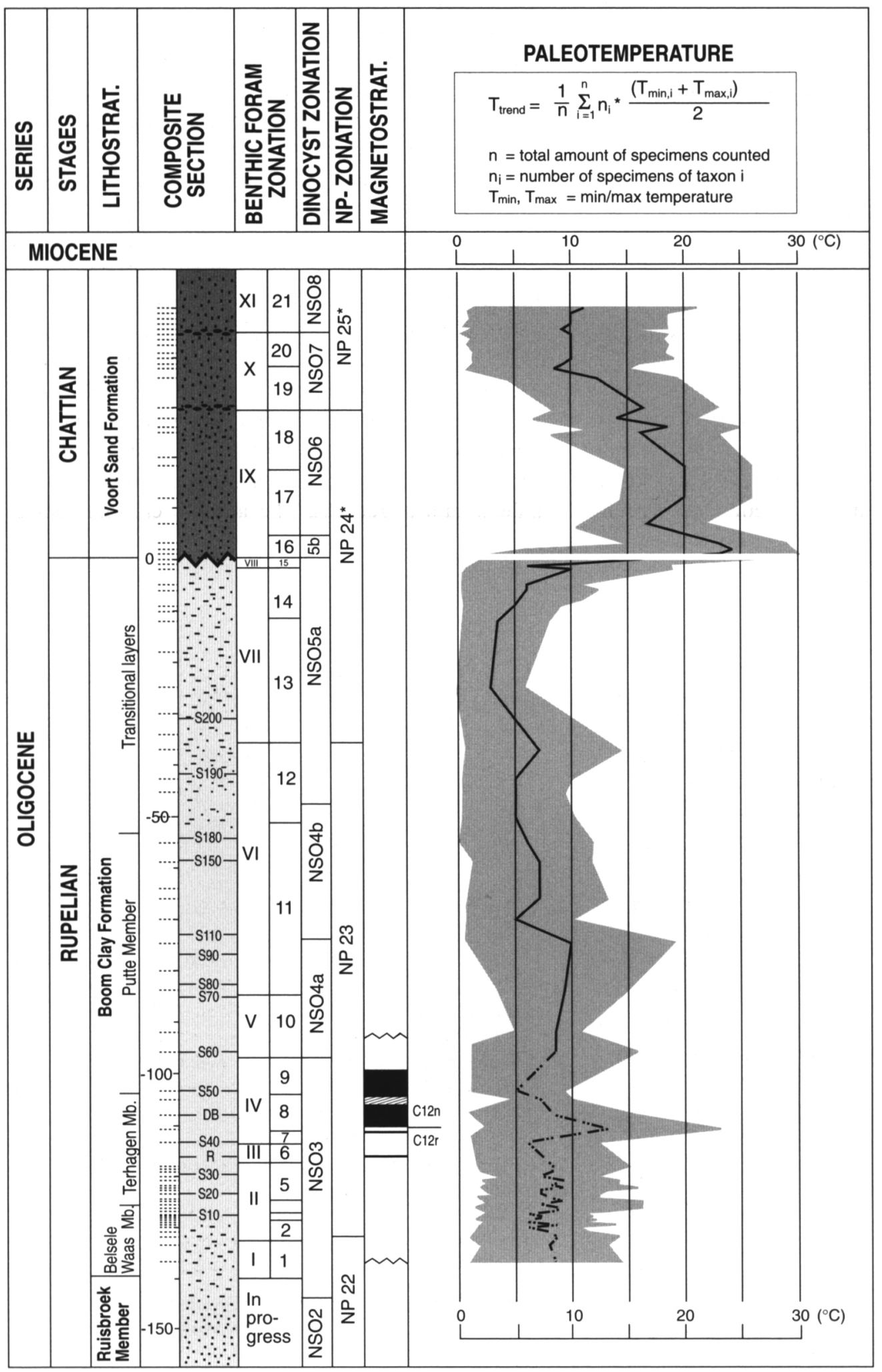

Fig. 4. Benthic foraminiferal paleotemperature curve for the Oligocene southern North Sea Basin successions. Grey zone indicates the reliability interval, as calculated from minimum and maximum values for the temperature range of taxa. Composite section and benthic foraminifer zonation after De Man et al., 2004; $\mathrm{NP}^{\star}$-zonation after Van Simaeys et al., 2004; dinocyst zonation after Van Simaeys et al., in press; magnetostratigraphy after Vandenberghe et al., 2001. Counts not exceeding 100 specimens per sample are indicated by a dashed line. Legend as in Fig. 3. 
Lenticulina, Pullenia, Hoeglundina, Spiroplectinella, Hansenisca, Angulogerina, etc.), and the calculated bottom water paleotemperatures never exceed $10^{\circ} \mathrm{C}$ (Fig. 4). Some rare Rupelian samples (i.e., $-110 \mathrm{~m}$, $-74 \mathrm{~m}$ and $-37 \mathrm{~m}$ in the $\mathrm{CS}$ ), however, are characterised by both cold- and warm temperate taxa (e.g., Quinqueloculina and Bolivina) and hence show slightly higher bottom water paleotemperatures. The base of the Chattian, on the contrary, is characterised by abundant warm temperate, tropical to subtropical taxa (i.e. Asterigerinoides, Elphidium, Cancris) and the calculated bottom water paleotemperatures exceed $20^{\circ} \mathrm{C}$ (Fig. 4). Higher up the Chattian, the warm temperate to subtropical species are less abundant, and cold-temperate taxa (i.e. Angulogerina, Lenticulina, Melonis, Ehrenbergina) become more frequent.

\section{Interpretation}

The most obvious climate change recognised in the Oligocene southern North Sea Basin successions is the major warming-event associated with the basal Chattian sediments. Although the attributed equation should not be used for determining absolute paleotemperatures, it is clear that the cold to cold-temperate Rupelian benthic foraminiferal assemblages are in strong contrast with the tropical to subtropical fauna as recorded from the basal Chattian sediments.

\section{A Late Oligocene Warm Episode?}

As the marked tropical to subtropical conditions for the basal Chattian sediments in the southern North Sea Basin clearly conflict with the general perception of a long-termed, pervasive global deterioration of the Paleogene climate, our findings need to be considered with caution. Do the tropical to subtropical Chattian deposits at Northern Hemisphere mid latitudes indicate temporal climate amelioration, or are these results biased by the simultaneous shallowing of the environment?

Other records of Late Oligocene warm temperate to subtropical conditions in the southern North Sea Basin have been documented in both the marine and continental realm. Estimated paleotemperatures, based on benthic foraminiferal assemblages from the Chattian unit-stratotype, i.e. the Doberg section in NW-Germany (Fig. 5), reveal annual average temperatures between $14^{\circ} \mathrm{C}$ and $19^{\circ} \mathrm{C}$ (Kohnen, 1995). Moreover, from the middle part of the Doberg section, Anderson et al. (1971) reports on the presence of
Miogypsina septentrionalis, a larger foraminifer, indicating tropical to subtropical conditions (Murray, 1973; Murray, 2002). Chattian Hiatella arctica molluscs from the well calibrated Kapellen and Rossenray profiles (Fig. 5; see also Ellermann, 1958; Indans, 1958) yield summer temperatures ${ }^{1}$ between 26.5 and $27^{\circ} \mathrm{C}$, while winter temperatures range between $20.5^{\circ} \mathrm{C}$ and $24.5^{\circ} \mathrm{C}$ (Strauch, 1968). The unexpected high paleotemperatures for the lower Chattian deposits, as calculated in our study, are within the range the previous paleotemperature reconstructions for the southern North Sea Basin.

Two localities from the southernmost margin of the Lower Rhine Embayment (Fig. 5) further yield substantial data on the Late Oligocene climatic conditions. The lake Rott sequence - consisting of lagoonal to lacustrine clay and brown coal deposits - belongs to the upper part of MP30 (Mörs, 2002) and hence has an approximate age of $24 \mathrm{Ma}$ (Utescher et al., 2000). The Enspel locality yields a rich and diversified flora containing fruits, seeds and leaves; a radiometric date of 25.8 Ma (or MP 28, Storch et al., 1996) indicates a Late Oligocene age. From these localities, Utescher et al. (2000) reconstruct the terrestrial paleoclimate, by using the coexistence approach on different paleobotanical records. The authors calculate Mean

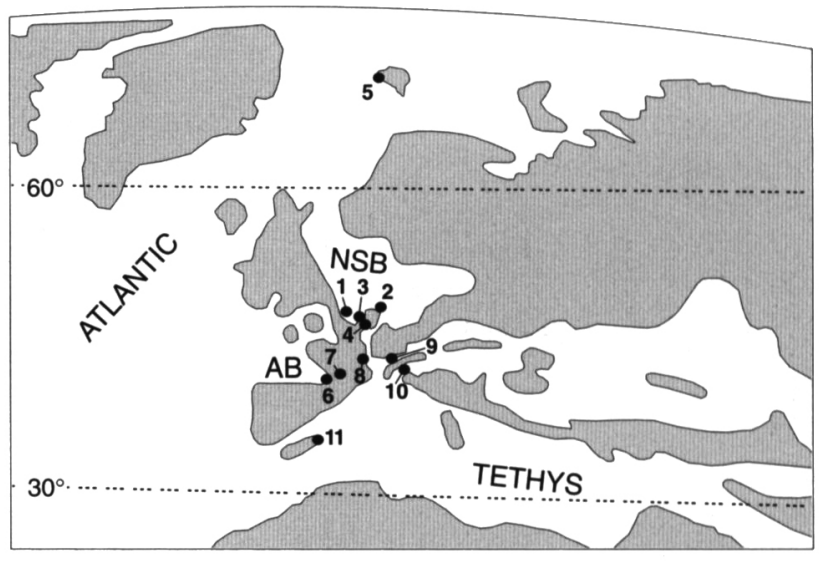

Fig. 5. Location of other Late Oligocene warm to subtropical records. 1. Rupelian unit stratotype (this study); 2. Chattian unit stratotype (Anderson et al., 1971; Kohnen, 1995); 3. Lower Rhine Embayment, i.e. Kapellen and Rossenray sections (Strauch, 1968); 4. Southernmost part of Lower Rhine Embayment, i.e. Lake Rott and Enspel (Schwarzbach, 1952; Utescher et al., 2000; Mörs, 2002); 5. Spitsbergen (Feyling-Hanssen \& Ulleberg, 1984); 6. Aquitaine Basin (Lauriat-Rage et al., 1993; Antunes \& Cahuzac, 1999); 7. Aquitaine molasse basin (Astruc et al., 2003); 8. Swiss Molasse (Berger, 1998); 9. Bavarian folded molasse (Uhlig et al., 2000); 10. Slovenian Sava Basin (Bruch \& Mosbrugger, 2002); 11. Mallorca (Ramos et al., 2001). Paleogeographic map modified from Ziegler (1990), Scotese \& Golanka (1992) and Sissingh (2003).

\footnotetext{
1 By investigating the numerical distribution, shell form and growth of recent Hiatella arctica, Strauch (1968) deduced quantitative temperature data from size measurements of adult fossil populations.
} 
Annual Temperatures (MAT) of $15.7-16.8^{\circ} \mathrm{C}$ for Enspel and $16.5-20.8^{\circ} \mathrm{C}$ for lake Rott; while the Warm Month Mean (WMM) for both localities respectively lies around $25^{\circ} \mathrm{C}$ and between $26-28^{\circ} \mathrm{C}$. The authors (Utescher et al., ibid.) interpret both the Enspel and lake Rott flora as to be deposited during very warm conditions. The warm nature of the lake Rott flora is furthermore supported by the remains of tropical palms (Schwarzbach, 1952) and the rich vertebrate fauna, containing crocodiles, snakes, Rhinocerotidae and Marsupialia (von Koeningswald \& Mosbrugger, 1989; Mörs, 1995, 1996, 2002). Feyling-Hanssen \& Ulleberg (1984) report on a peculiar benthic foraminiferal assemblage from Sarsbukta, Spitsbergen (Fig. 5): up to $\sim 10-20 \%$ of the benthic foraminifera consist of Asterigerinoides cf. guerichi; hence this association can tentatively be attributed to the early Chattian 'Asterigerina-Horizon'. Recent representatives of this genus, however, show clear affinity to shallow, warm temperate to subtropical conditions (Fig. 2). This observation suggests much warmer conditions on Spitsbergen during the Late Oligocene as compared to the present Arctic climate.

Several other studies report on Late Oligocene warm temperate to subtropical conditions in NW Europe: in the Aquitaine Basin (SW France, see Fig. 5), the Escornebeou sections have been ascribed to the Chattian based on the reported P22 (planktonic foraminifera), the NP25 (nannoplankton) calcareous microfossil assemblages (Antunes \& Cahuzac, 1999) and based on Sr-dating (foraminiferal tests are dated as $25.8 \mathrm{Ma} \pm 0.31 \mathrm{Ma}$, Cahuzac et al., 1997). The warm, at least subtropical climate during the deposition of these Chattian successions is inferred from the presence of Tomistomine crocodilians, which cannot live at temperatures lower than $10^{\circ} \mathrm{C}$ as a minimum during the coldest season (Antunes \& Cahuzac, 1999). Other climate indicators, pointing towards warm, tropical conditions, are the presence of numerous larger foraminifera (i.e. Nummulites bouillei ${ }^{2}$ and Miogypsinoides), the abundance of hermatypic corals ( $>120$ species), echinoids, molluscs and sharks ${ }^{3}$; for an overview see Lauriat-Rage et al. (1993). Also the vertebrate fauna from the Aquitaine molasse basin (Fig. 5) reveals several taxa with affinities to warm conditions: Astruc et al. (2003) reports on vertebrate bearing localities with Rhinocerotidae in MP25/26 (early Chattian) and crocodile-, lizard-, snake- and Marsupialia remains assigned to MP26 (Chattian).
From the Swiss Molasse (Fig. 5), Berger (1998) reports on the 'Rochette' fossil assemblage, of which the 'warm character' is clearly indicated by the abundance of Lygodium ${ }^{4}$ and by the large size of the turtles and crocodiles. These Lower Freshwater Molasse localities are dated by mammals (MP29, $\sim 25.5 \mathrm{Ma}$ according to Berger, 1992) and charophytes (notata zone, Late Oligocene). Uhlig et al. (2000) report on tropical, estuarine environments with mangrove vegetation from the Lower Cyrena Beds in the Bavarian folded molasse (Fig. 5). These beds correspond to the upper part of mammal zone MP24 and hence can be attributed to the lower Chattian. Bruch \& Mosbrugger (2002) reconstruct the Late Oligocene paleoclimate in the Slovenian Sava Basin (Fig. 5) and document warm temperate, humid climate conditions with low annual variation. Ramos et al. (2001) report on the presence of crocodile and turtle remains (mean monthly temperature $\sim 20^{\circ} \mathrm{C}$ ) and elements of rain forest vegetation ${ }^{5}$ from the Late Oligocene lacustrine Cala Blanca Formation, Mallorca (Fig. 5). Stratigraphic age control is based on charophytes, palynomorphs and rodent fossil remains (Ramos et al., 2001)

From this, and previous studies - using independent tools of paleoclimate reconstruction - it becomes clear that warm to tropical conditions emerged during the Late Oligocene in NW-Europe. This widespread major warming pulse suggests correlation with the global Late Oligocene Warming Event (LOWE, Zachos et al., 2001); this assumption is supported by dinoflagellate cyst correlations (Van Simaeys, 2004). The LOWE - calibrated against magnetochron C8 induced a major sea level rise, which seems to be genetically related to the early Chattian transgression in the southern North Sea Basin (Van Simaeys, 2004).

Quantitative data from Northern Hemisphere mid latitude Oligocene deposits is limited, poorly calibrated (Buchardt, 1978), or altered by diagenesis (Attendorn, 1995). Detailed oxygen isotope analysis on benthic foraminifera and incrementally sampled otoliths and bivalves from Belgian Oligocene deposits should enable recognition of the Late Oligocene Warming Event in the stratotype regions (De Man et al., in prep.).

\footnotetext{
2 Recent Nummulitidae occur in tropical conditions with sea surface temperatures between $24-34^{\circ} \mathrm{C}$ (Langer \& Hottinger, 2000).

3 i.e. Carcharhiniforms, suggesting at least moderately warm waters (Antunes \& Cahuzac, 1999).

4 Leaves of a lower vascular plant of which the recent Lygodium palmatum is found in Florida (Berger, 1998).

5 i.e. Sabal, Sapindus, Ficus.
} 


\section{Conclusions}

Quantitative analysis of benthic foraminifera from several boreholes throughout the Oligocene southern North Sea Basin successions enables the reconstruction of both paleoenvironment and paleoclimate changes associated with the Rupelian-Chattian transition in their type region.

By determining the Fisher $\alpha$ diversity index, the proportion of hyaline, porcellaneous and agglutinated taxa, and the relative abundance of planktonic foraminifera $(\mathrm{P} \%)$, it is shown that the lower part of the Rupelian is characterised by normal marine shelf conditions with temporal open connections towards the ocean realm and water depths around $100 \mathrm{~m}$. The upper Rupelian successions show a gradual shallowing and the realisation of a poorly ventilated and more isolated marine environment. The base of the Chattian sequence, on the contrary, is characterised by marginal marine to brackish-marine conditions, with water depths not exceeding $20 \mathrm{~m}$. Higher up the Chattian successions, conditions return to a normal marine environment.

A major climate change coincides with the RupelianChattian unconformity in the southern North Sea Basin: the unexpected tropical to subtropical benthic foraminiferal assemblages from the basal Chattian sediments in the southern North Sea Basin are in strong contrast with the cold to cold-temperate Rupelian fauna. Previous studies - using independent tools of paleoclimate reconstruction - confirm that warm to tropical conditions emerged during the Late Oligocene in NW-Europe. This widespread major warming pulse suggests correlation with the global Late Oligocene Warming Event (LOWE, Zachos et al., 2001); an assumption supported by dinoflagellate cyst correlations (Van Simaeys, 2004).

\section{Acknowledgements}

The authors would like to express their gratitude to Henk Brinkhuis, Stefaan Revets, Robert Speijer and Etienne Steurbaut for stimulating discussions. Careful reviews were provided by Gitte V. Laursen and Bruno Cahuzac. Thanks are due to both of them. EDM gratefully acknowledges the support of the DWTC-Brussels (Grant WI/36/C03) and SVS acknowledges support from the University of Leuven (Special Faculty Section nr. 12692 Grant).

\section{References}

Anderson, A.J., Hinch, W., Martini, E., Müller, C. \& Ritzkowski, S., 1971. Chattian. Giornale di Geologia 37(2): 69-79.

Antunes, M. \& Cahuzac, B., 1999. Crocodilian faunal renewal in the Upper Oligocene of Western Europe. Comptes rendus de l'académie des sciences serie II Fascicule A-Sciences de la terre et des planètes 328(1): 67-72.

Astruc, J.G.Hugueney, M., Escarguel, G., Legendre, S., Rage, J.-C., Simon-Coinçon, R., Sudre, J. \& Sigé, B., 2003. Puycelci, a new vertebrate-bearing locality in the Aquitaine molassic basin. Density and continuity of the Paleogene biochronologic record in the Quercy and peripheral basins area. Geobios 36(6): 629-648.

Attendorn, $1995 . \quad \delta^{13} \mathrm{C}$ und $\delta^{18} \mathrm{O}$-Isotopenverhaltnisse von Pectiniden des Chatt der Niederrheinischen Bucht, NWDeutschland. Neues Jahrbuch fur Geologie und Palaontologie Abhandlungen 198(1/2): 223-232.

Beckmann, J.P., 1953. Die Foraminiferen der Oceanic Formation (Eocaen-Oligocaen) von Barbados, Kl. Antillen. Eclogae Geologicae Helvetiae 46(2): 301-412.

Berger, J.-P., 1992. Correlative chart of the European Oligocene and Miocene: Application to the Swiss Molasse Basin. Eclogae Geologicae Helvetiae 85(3): 573-609.

Berger, J.-P., 1998. 'Rochette' (Upper Oligocene, Swiss Molasse): a strange example of a fossil assemblage. Review of Palaeobotany and Palynology 101: 95-110.

Bohaty, S. \& Zachos, J.C., 2003. Significant Southern Ocean warming event in the late middle Eocene. Geology, 31(11): 1017-1020.

Bruch, A.A. \& Mosbrugger, V., 2002. Palaeoclimate versus vegetation reconstruction - palynological investigations on the Oligocene sequence of the Sava Basin, Slovenia. Review of Palaeobotany and Palynology 122: 117-141.

Buchardt, B., 1978. Oxygen isotope palaeotemperatures from the Tertiary period in the North Sea area. Nature 275: 121-123.

Cahuzac, B., Turpin, L. \& Bonhomme, P., 1997. Sr isotope record in the area of the Lower Miocene historical stratotypes of the Aquitaine Basin (France). In: Montanari, A., Odin, G.S., Coccioni, R. (eds), Miocene stratigraphy: an integrated approach. Developments in Paleontology and Stratigraphy. Elsevier (Amsterdam): 33-56.

Corliss, B.H., 1981. Deep-sea benthonic foraminiferal faunal turnover near the Eocene/Oligocene boundary. Marine Micropaleontology 6: 367-384.

De Man, E., Van Simaeys, S., De Meuter, F., King, C. \& Steurbaut, E., 2004. Oligocene benthic foraminiferal zonation for the southern North Sea Basin. Bulletin van het Koninklijk Belgisch Instituut voor Natuurwetenschappen - Aardwetenschappen 74 supplement: 177-195.

De Man, E., Vandenberghe, N., Van Simaeys, S. \& Ivany, L., in preperation. $\delta^{18} \mathrm{O}$ record of the Rupelian-Chattian boundary in NE Belgium.

Doppert, J.W.C. \& Neele, N.G., 1983. Biostratigraphy of marine Paleogene deposits in the Netherlands and adjacent areas. Mededelingen Rijks Geologische Dienst 37(2): 4-79.

Ellermann, C., 1958. Die mikrofaunistische Gliederung des Oligozäns im Schacht Kapellen bei Moers (Niederrhein). Fortschritte Geologie von Rheinland und Westfalen 1: 205-214.

Feyling-Hanssen, R.W. \& Ulleberg, K., 1984. A Tertiary-Quaternary section at Sarsbukta, Spitsbergen, Svalbard, and its foraminifera. Polar Research 2 n.s.: 77-106. 
Grimm, K.I. \& Steurbaut, E., 2001. Foraminiferal biofacies analysis of the Boom Clay in the Rupel area (Oligocene, Belgium) and correlation with the Mainz Basin (Germany). In: N. Vandenberghe (ed), Contributions to the Paleogene and Neogene Stratigraphy of the North Sea Basin. Aardkundige Mededelingen 11. Leuven University Press, Leuven: 9-20.

Haake, F.-W., 1962. Untersuchungen an der Foraminiferen-Fauna im Wattengebiet zwischen Langeoog und dem Festland. Meyniana 12: 25-64.

Hofker, J., 1977. The foraminifera of dutch tidal flat and salt marches. Netherlands Journal of Sea Research 11 (3/4): 223-296.

Hooyberghs, H., Vercauteren, T., De Meuter, F. \& Symons, F., 1992. Foraminiferal studies in the Boom Formation. Ministerie van Economische Zaken, Belgische Geologische Dienst, Professional paper 8(258): 1-46.

Indans, J., 1958. Mikrofaunistische Korrelationen im marinen Tertiär der Niederrheinischen Bucht. Fortschritte Geologie von Rheinland und Westfalen 1: 223-238.

Indans, J., 1965. Nachweis des Asterigerinen-Horizontes im Oberoligozän des Dobergs bei Bünde/Westfalen. Neues Jahrbuch Geologie und Paläontologie, Abhandlungen 123(1): 20-24.

Ivany, L.C., Nesbitt, E.A. \& Prothero, D.R., 2003. The marine Eocene-Oligocene transition: a synthesis. In: Prothero, D.R., Ivany, L.C. \& Nesbitt, E.A. (eds), From Greenhouse to Icehouse. The marine Eocene-Oligocene transition. Columbia University Press, New York: 522-534.

Jarke, J., 1961. Die Beziehungen zwischen hydrographischen Verhältnissen, Faziesentwicklung und Foraminiferenverbreitung in der heutigen Nordsee als Vorbild für die Verhältnisse während der Miocän-Zeit. Meyniana 10: 21-36.

King, C., 1983. Cainozoic micropalaeontological biostratigraphy of the North Sea. Report Institute of Geological Sciences 82(7): 1-40.

King, C., 1989. Cenozoic of the Norh Sea. In: D.G. Jenkins \& J.W. Murray (eds), Stratigraphical atlas of fossil foraminifera. British micropalaeontological society series. Ellis Horwood Limited (Chichester): 418-489.

Kohnen, O., 1995. Paläotemperaturen aus dem Oberoligozän des Norddeutschen Beckens. Neues Jahrbuch für geologie und palaontologie - Abhandelungen 198(1/2): 233-241.

Langer, M. \& Hottinger, L., 2000. Biogeography of selected larger foraminifera. Micropaleontology 46(1): 105-126.

Lauriat-Rage, A., Brébion, Ph., Cahuzac, B., Chaix, Ch., Ducasse, O., Ginsburg, L., Janin, M.-C., Lozouet, P., Margerel, J.-P., Nascimento, A., Pais, J., Poignant, A., Pouyet, S. \& Roman, J., 1993. Palaeontological data about the climatic trends from Chattian to present along the Northeastern Atlantic frontage. Ciencias da Terra, Universidade Nova Lisboa (1st Congress R.C.A.N.S., Lisboa, 1992) 12: 167-179.

Lommerzheim, A., 1991. Mikropaläontologische Indikatoren für Paläoklima und Paläobathymetrie in der borealen Oberkreide: Bohrung Metelen 1001. Facies 24: 183-254.

Miller, K.G., Fairbanks, R.G. \& Mountain, G.S., 1987. Tertiary oxygen isotope synthesis, sea level history, and continental margin erosion. Paleoceanography 2(1): 1-19.

Miller, K.G., Feigenson, M.D., Wright, J.D. \& Clement, B.M., 1991. Miocene isotope reference section, Deep Sea Drilling Project site 608: an evaluation of isotope and biostratigraphic resolution. Paleoceanography 6(1): 33-52.

Miller, K.G. Mountain, G.S., Browning, J.V., Kominz, M., Sugerman, P.J., Christie-Blick, N., Katz, M.E. \& Wright, J.D., 1998. Cenozoic global sea level, sequences, and the New Jersey transect: results from coastal plain and continental slope drilling. Reviews of Geophysics 36(4): 569-601.
Mörs, T., 1995. Die Sedimentationsgeschichte der Fossillagerstätte Rott und ihre Alterseinstufung anhand neuer Säugetierfunde (Oberoligozän, Rheinland). Courier des Forschungs-Instituts Senckenberg 187: 101-115.

Mörs, T., 1996. Die Säugetiere der oberoligozänen Fossillagerstätte Rott bei Bonn (Rheinland). Decheniana 149: 205-232.

Mörs, T., 2002. Biostratigraphy and paleoecology of continental Tertiary vertebrate faunas in the Lower Rhine Embayment (NWGermany). Netherlands Journal of Geosciences 81(2): 177-183.

Murray, J.W., 1973. Distribution and ecology of living benthic foraminifera. Heinemann, London, $274 \mathrm{pp}$.

Murray, J.W., 1976. A method of determining proximity of marginal seas to an ocean. Marine Micropaleontology, 22: 103-119.

Murray, J.W., 1984. Benthic Foraminifera: some relationships between ecological observations and palaeoecological interpretations, Benthos '83; 2nd Int. Symp. Benthic Foraminifera, Pau, April 1983: 465-469.

Murray, J.W., 1991. Ecology and Palaeoecology of benthic foraminifera. Longman Scientific and Technical, NewYork, $341 \mathrm{pp}$.

Murray, J.W., 2002. Introduction to benthic foraminifera. In: Haslett, S.K. (ed) Quaternary environmental micropalaeontology. Arnold, London: 5-13.

Ramos, E., Cabrera, L., Hagemann, H.W., Pickel, W. \& Zamarreño, I., 2001. Palaeogene lacustrine record in Mallorca (NW Mediterranean, Spain): depositional, palaeogeographic and palaeoclimatic implications for the ancient southeastern Iberian margin. Palaeogeography, Palaeoclimatology, Palaeoecology 172: 1-37.

Schwarzbach, M., 1952. Aus der Klimageschichte des Rheinlandes. Geologische Rundschau 40: 128-136.

Scotese, C.P. \& Golanka, J., 1992. Paleogeographic atlas, PALEOMAP progress report 20-0692. Arlington, University of Texas: 34 pp.

Sissingh, W., 2003. Tertiary paleogeographic and tectonostratigraphic evolution of the Rhenish Triple Junction. Palaeogeography, Palaeoclimatology, Palaeoecology 196: 229-263.

Storch, G., Engesser, B. \& Wuttke, M., 1996. Oldest fossil record of gliding in rodents. Nature 379: 439-441.

Strauch, F., 1968. Determination of Cenozoic sea-temperatures using Hiatella arctica (Linné). Palaeogeography, Palaeoclimatology, Palaeoecology 5: 213-233.

Uhlig, U., Reichenbacher, B. \& Bassler, B., 2000. Mammals, fish otoliths and charophytes from the Lower Cyrena Beds (Oligocene) of the folded molasse of Bavaria (Murnau syncline). Eclogae Geologicae Helvetiae 93(3): 503-516.

Ulleberg, K., 1987. Foraminiferal zonation of the Danish Oligocene sediments. Bulletin geological Society Denmark 36: 191-202.

Utescher, T., Mosbrugger, V. \& Ashraf, A.R., 2000. Terrestrial Climate Evolution in Northwest Germany Over the Last 25 Million years. Palaios 15: 430-449.

Vandenberghe, N., Hager, H., Van Den Bosch, M., Verstraelen, A., Leroi, S., Steurbaut, E., Prüfert, J. \& Laga, P., 2001. Stratigraphic Correlation by calibrated well logs in the Rupel Group between North Belgium, the Lower-Rhine area in Germany and Southern Limburg and the Achterhoek in The Netherlands with list of figures and in annex correlation plates. In: N. Vandenberghe (ed), Contributions to the Paleogene and Neogene Stratigraphy of the North Sea Basin. Aardkundige Mededelingen 11. Leuven University Press, Leuven: 69-84.

Van Simaeys, S., 2004. The Rupelian-Chattian boundary in the North Sea Basin and its calibration to the international timescale. Netherlands Journal of Geosciences / Geologie en Mijnbouw 83(3): 241-248 
Van Simaeys, S., De Man, E., Vandenberghe, N., Brinkhuis, H. \& Steurbaut, E., 2004. Stratigraphic and palaeoenvironmental analysis of the Rupelian-Chattian transition in the type region: evidence from dinoflagellate cysts, foraminifera and calcareous nannofossils. Palaeogeography, Palaeoclimatology, Palaeoecology 208: 31-58.

Van Simaeys, S., Brinkhuis, H., Pross, J., Williams, G. \& Zachos, J., submitted. Arctic dinoflagellate migration marks the Mid Oligocene Climatic Minimum. Geology.

Van Simaeys, S., Munsterman, D. \& Brinkhuis, H., in press. Oligocene dinoflagellate cyst biostratigraphy of the southern North Sea Basin. Review Palaeobotany and Palynology.

Von Koeningswald, W. \& Mosbrugger, V., 1989. Rott im Überblick. In: W. Von Koeningswald (ed), Die Fossillagerstätte Rott bei Hennef im Siebengebirge. Rheinlandia, Siegburg: 81-82.

Wong, T.E., 1976. Tertiary stratigraphy and micropaleontology of the Guiana Basin. Geologie en Mijnbouw Dienst Suriname, Mededeling 25: 13-107.

Wood, K.C., Miller, K.G. \& Lohmann, G.P., 1985. Middle Eocene to Oligocene benthic foraminifera from the Oceanic Formation, Barbados. Micropaleontology 31(2): 181-197.
Zachos, J.C., Lohmann, K.C., Walker, J.D.G. \& Wise, S.W., 1993. Abrupt climate change and transient climates during the Paleogene: a marine perspective. Journal of Geology 101: 191-213.

Zachos, J.C., Opdyke, B.N., Quinn, T.M., Jones, C.E. \& Halliday, A.N., 1999. Early Cenozoic glaciation, Antarctic weathering, and seawater $87 \mathrm{Sr} / 86 \mathrm{Sr}$ : is there a link? Chemical Geology 161 : 165-180.

Zachos, J.C., Pagani, M., Sloan, L., Thomas, E. \& Billups, K., 2001. Trends, rhythms, and aberrations in global climate $65 \mathrm{Ma}$ to present. Science 292: 686-693.

Zachos, J.C., Quinn, T.M. \& Salamy, S., 1996. High-resolution (104years) deep-sea foraminiferal stable isotope records of the Eocene-Oligocene climate transition. Paleoceanography 11(3): 251-266.

Zachos, J.C., Stott, L.D. \& Lohmann, K.C, 1994. Evolution of early Cenozoic marine temperatures. Paleoceanography 9: 353-387.

Ziegler, P.A., 1990. Geological atlas of western and central Europe. Shell Internationale Petroleum Maatschappij B.V. (Den Haag), 239 pp. 